\title{
ADMINISTRATIVE EXPENSES IN SUCCESSIVE INSOLVENCY PROCEEDINGS
}

WHEN a bankruptcy court obtains jurisdiction over a debtor's property, for purposes of either liquidating or reorganizing the estate, it must frequently determine what recognition should be given to allowances made in prior proceedings of a similar nature in state or federal courts. These allowances, which represent the costs of administering the prior proceeding, may comprise the fees of receivers, trustees and attorneys, the expenses incurred in preserving the debtor's estate, and, in some cases, the costs of conducting the business of the debtor while under the jurisdiction of the court. The power of the bankruptcy court to review such allowances and the priority of payment to which they are entitled depend upon the nature of the service for which the allowance was granted and upon the character of the proceedings involved. This Comment will consider the various types of allowances under three headings: first, when proceedings for adjudication as a bankrupt supersede a receivership; second, when reorganization proceedings under Section 77B of the Bankruptcy Act supersede either a receivership or a bankruptcy; and third, when an unsuccessful reorganization is followed by liquidation or by return of the property to a prior receiver or trustee, or to the debtor.

Where a petition in bankruptcy is filed affecting a corporation which is already in receivership, the trustee is faced with the problem of acquiring the property from the jurisdiction of the receivership court. If the receivership preceded the filing of the petition by more than four months, well settled principles of comity generally preclude the trustee from seizing the property, and consequently the bankruptcy proceeding must fail. ${ }^{1}$ If bankruptcy intervenes within four months of the inauguration of the receivership, however, the bankruptcy court obtains jurisdiction over the estate as of the date of filing the petition. ${ }^{2}$

Because of the paramount jurisdiction enjoyed by bankruptcy courts, any allowances for fees made by the receivership court after the filing of the petition in bankruptcy is subject to review in the bankruptcy proceeding. ${ }^{8}$

1. Blair v. Brailey, 221 Fed. 1 (C. C. A. 5th, 1915); Hoover v. Mortgage Co. for America, 290 Fed. 891 (C. C. A. 9th, 1923). But cf. In re Weedman Stove Co., 199 Fed. 948 (E. D. Ark. 1912).

2. In re Williams, 240 Fed. 788 (N. D. Ohio 1917); In re Diamond's Estate, 259 Fed. 70 (C. C. A. 6th, 1919) ; cf. In re Watts and Sachs, 190 U. S. 1 (1903) (bankruptcy following assignment for benefit of creditors).

3. Gross v. Irving Trust Co., 289 U. S. 342 (1933); Taylor v. Sternberg, 293 U. S. 470 (1935) ; In re Rogers, 116 Fed. 435 (S. D. Ga. 1902) (state court cannot turn res over to bankruptcy court on condition that it pay the sum ordered by the state court); Hume v. Myers, 242 Fed. 827 (C. C. A. 4th, 1917) ; Moore v. Garragucz, 83 F. (2d) 139 (C. C. A. 9th, 1936). Some state courts, however, formerly insisted upon their right to pay the allowances before turning the res over to the bankruptcy court. See (1932) 41 Yale L. J. 1234, 1235. 
Moreover, if actual payments to receivers or attorneys after that time are excessive, the trustee may recover the excess in a summary proceeding. ${ }^{*}$ The right to review allowances made before the filing of the petition generally will depend upon the finality of the order of the receivership court. Immediate payment of the allowance, or even an order directing such payment out of cash in hand, cannot be attacked collaterally by the trustee in bankruptcy. ${ }^{5}$ But in the usual receivership, the court will not take final action upon fees until the accounting at the termination of the proceeding; when bankruptcy intervenes before that time, the right to fix compensation and to determine its priority of payment passes to the bankruptcy court. ${ }^{\sigma}$ In exercising their discretionary power over fees, however, bankruptcy courts have attached considerable weight to the receivership court's evaluation of a reasonable award.7 It has even been suggested that where no allowance has been set in the prior proceeding, application should be made to the receivership court to fix fees which will reasonably compensate receivers and attorneys for their services. ${ }^{8}$ Since the receivership court is clearly in a more advantageous position to adjudge the value of these services, some such practice would seem advisable, provided that bankruptcy courts do not hesitate to exercise their prerogative to scale down exorbitant and unreasonable fees. Although the Bankruptcy Act grants no priority to the costs of administering prior proceedings, ${ }^{3}$ allowances for fees which have been passed upon by a bankruptcy court will generally be paid in full. They will thus take precedence over unsecured claims. ${ }^{10}$ Moreover, when the services involved were clearly necessary to the preservation of the estate ${ }^{11}$ or where secured creditors actually or impliedly have consented, ${ }^{12}$ such allowances may be paid even in advance of secured claims, provided the assets of the bankrupt would otherwise be insufficient to satisfy them.

As in the case of fees, the expenses and obligations of a receiver in preserving the property and in running the business of a debtor are subject to review in a subsequent bankruptcy, if the expenditures occurred after the filing of the petition or if no final accounting or judicial approval of

4. See In re Mloore, 42 F. (2d) 475 (N. D. Ga. 1930).

5. See Taylor v. Sternberg, 293 U. S. 470, 472 (1935); In re Williams, 240 Fed. 788, 789 (N. D. Ohio 1917); In re Diamond's Estate, 259 Fed. 70, 74 (C. C. A. 6th, 1919); Moore v. Scott, 55 F. (2d) 863, \&65 (C.C.A. 9th, 1932).

6. In re Insull Utility Investments, Inc., 74 F. (2d) 510 (C.C. A. 7 th, 1935).

7. See $i d$, at 515 .

8. (1932) 41 YALE L. J. 1234, 1236.

9. $\$ 64(\mathrm{~b}), 44$ StAT. 666 (1926), 11 U.S.C. $\$ 104(b)(1934)$, which sets the priorities in the bankruptcy proceedings, grants pricrity to ". . . (1) the actual and necessary cost of preserving the estate subsequent to the filing of the netition ...."

10. See In re Paramount Publix Corp., 10 F. Supp. 504, 507 (S. D. X. Y..1934).

11. Paine v. Archer, 233 Fed. 259 (C.C. A. 9 th, 1916).

12. In re Quemahoning Creek Cral Co., 15 F. (2d) 58 (WV. D. Pa. 1920). 
disbursements had taken place prior to that time. ${ }^{13}$ Very often, however, a receivership court will authorize a receiver in advance to incur those liabilities which are necessary to carry out the purpose of the proceeding, and to issue receivership certificates therefor. ${ }^{14}$ These are usually given a stated priority over the various creditors. ${ }^{16}$ When the purpose of the expenditures is to preserve the estate, the certificates will usually take priority over secured claims. ${ }^{18}$ Liabilities which are incurred merely to carry on the business of the debtor generally take priority over the claims of unsecured creditors ${ }^{17}$ and over claims of secured creditors who have consented to or authorized them. ${ }^{18}$ A notable exception to this rule has been made in the case of public service corporations. ${ }^{19}$ In view of the dearth of authority on the subject, it is difficult to determine whether or not a bankruptcy court may disallow claims based on certificates authorized in a prior receivership, but where these certificates represent a lien upon the property of the debtor created within four months of an impending bankruptcy, it is possible that the bankruptcy court could set aside the lien under Section 67(c) of the Bankruptcy Act, which provides for the displacement of liens under certain conditions. ${ }^{20}$

In those cases in which the right to review the obligations of an earlier receivership exists, the bankruptcy courts have generally applied the same rules of priority as obtain in equity proceedings and have satisfied such obligations ahead of secured claims when they were necessary to the preserva-

13. It re Benwood Brewing Co., 202 Fed. 326 (N. D. W. Va. 1913); Smith v. Shenandoah Valley Nat. Bank of Winchester, 246 Fed. 379 (C. C. A. 4th, 1917).

14. 1 Gerdes, Corporate Reorganizations (1936) $\$ 396$.

15. Ibid.

16. 16 Fletcher, Cyc. Corporations (perm. ed. 1931) §7947.

17. Ibid.

18. Kent v. Lake Superior Ship Canal, Ry., and Iron Co., 144 U. S. 75 (1892); see Baltimore Bldg. \& Loan Ass'n v. Alderson, 90 Fed. 142, 147 (C. C. A. 4th, 1898).

If the debts have been improvidently incurred, or have not been authorized by the receivership court and were not necessary to the preservation of the estate, they are relegated to the position of ordinary unsecured claims. Piedmont Corp. v. Gainesville and N. W. R. R., 30 F. (2d) 525 (N. D. Ga. 1929); Darling v. Cornstalk Products Co., 54 F. (2d) 670 (E. D. Ill. 1931); 16 Fletcher, CyC. Corporations (perm. ed. 1931) §7947.

19. For a discussion of claims in public service company receiverships, see FitzGibbon, The Present Status of the Six Months Rule (1934) 34 Cor. L. REv. 230. In some cases priority has been granted to six months claims in receiverships of private corporations. See 2 GERDES, op. cit. supra note $14, \S 675$.

20. 30 Stat. 564 (1898), 11 U. S. C. $\$ 107$ (c) (1934). A lien created within four months before the filing of a petition in bankruptcy is dissolved by the adjudication “. . . if (1) it appears that said lien was obtained and permitted while the defendant was insolvent and that its existence and enforcement will work a preference, or (2) the party or parties to be benefited thereby had reasonable cause to believe the defendant was insolvent and in contemplation of bankruptcy, or (3) that such lien was sought and permitted in fraud of the provisions of this Act ..." 
tion of the estate 21 or where the consent of secured creditors had been obtained. ${ }^{22}$ In other cases of authorized expenditures the claims of third parties against the receivers for receivership expenses have been preferred over unsecured claims against the estate. ${ }^{23}$ But when the obligations were improvidently incurred ${ }^{24}$ or were not authorized by the receivership court, generally they have been denied any priority unless they happen to fall within the priority section ${ }^{28}$ of the Bankruptcy Act which grants priority to taxes, wages earned within three months of the fling of the petition, and claims entitled to priority under state law. Since obligations of prior receiverships will seldom be satisfied in full unless they are given a priority, at least over unsecured claims, strong arguments may be advanced for granting the requisite priority whenever these obligations have been duly authorized by a receivership court. If receivership certificates are not accorded priority 27 in bankruptcy, receivers will encounter considerable difficulty in securing credit until after the four months period has passed.23

A reorganization proceeding under Section $77 \mathrm{~B}$ is designed for the rehabilitation and ultimate reestablishment of the debtor corporation as a going concern. ${ }^{29}$ To facilitate the reorganization process by eliminating jurisdictional conflicts, the Act provided that the institution of proceedings under it should automatically suspend prior receiverships and bankruptcies, which may thus be superseded irrespective of the time when they were commenced.30 Fair treatment of the costs of administering these prior proceedings is insured by the specific direction to the reorganization judge in Subsection (i) to ". . . make such orders as he may deem equitable for the protection of obligations incurred by the receiver or prior trustee and for the payment of such reasonable administrative expenses and allowances in the prior proceeding as may be fixed by the court appointing said receiver or prior trustee

21. Jerome v. MrCarter, 94 U. S. 734 (1876); Paine v. Archer, 233 Fed. 259 (C. C. A. 9th, 1916).

22. In re Erie Lumber Co., 150 Fed. 817 (S. D. Ga. 1906); In re Benwood Brewing Co., 202 Fed. 326 (N. D. W. Va. 1913) ; Smith v. Shenandoah Valley Nat. Banl: of Winchester, 246 Fed. 379 (C. C. A. 4th, 1917).

23. In re J. H. Alison Lumber Co., 137 Fed. 643 (S. D. Ga. 1905); In re Benwood Brewing Co., 202 Fed. 326 (N. D. W. Va. 1913); 5 Resmitgo:i, BAsknurter (4th ed., 1936) §2098.

24. In re Alison Lumber Co., 137 Fed. 643 (S. D. Ga. 1905).

25. In re Benwood Brewing Co., 202 Fed. 326 (N. D. W. V3. 1913); Smith v. Shenandoah Nat. Bank of Winchester, 246 Fed. 379 (C. C. A. 4th, 1917).

26. $\$ 64$.

27. See 1 Gerdes, loc. cit. supra note 14.

28. See (1932) 41 Yale L. J. 1234, 1236.

29. See In re Island Park Associates, Inc, 77 F. (2d) 334, 337 (C. C. A. 2d, 1935); Brockett v. Winkle Terra Cotta Co., 81 F. (2d) 949, 953 (C. C.A. 8th, 1936).

30. BANKRUPTCY ACt \$77B(i), 48 StAT. 920, 11 U. S. C. $\$ 207$ (i) (1934); In re Greyling Realty Corp., 74 F. (2d) 734 (C. C. A. 2d, 1934), cerl. denicd, sub. nom. Troutman r. Compton, 294 U. S. 725 (1935). 
Since this section does not purport to define the scope of a reorganization court's control over the administration of prior proceedings, the right to review allowances is probably no broader in reorganization than in bankruptcy. ${ }^{31}$ Where the right to review is present, however, as where the superseded court failed to pass on the allowances or did not order them paid before reorganization intervened, the various costs of administration are treated differently in reorganization. A distinction seems to have been made for the first time ${ }^{32}$ between "reasonable administrative expenses and allowances," which must be "paid" in the reorganization proceedings, and "obligations," which need only be "protected." Although no hard line has yet been drawn by the courts between these two classifications, it seems that the term "obligation" comprises the various liabilities which the prior receiver or trustee might incur in managing the property of the debtor ${ }^{33}$ such as salaries, supplies, wages, rent and taxes, while "administrative expenses and allowances" represent the more technical aspects of the court proceeding such as filing fees, fees and expenses of receivers or trustees, and their attorneys and employees.

In dealing with those "administrative expenses and allowances" which are reviewable ${ }^{34}$ in reorganization, the court is empowered to scale down prior allowances which are not considered reasonable, ${ }^{35}$ although the bankruptcy practice of treating determinations made by the superseded court as presump-

31. Shulman v. Wilson-Sheridan Hotel Co., 301 U. S. 172 (1937); In re 7000 South Shore Drive Bldg. Corp., S6 F. (2d) 499 (C. C. A. 7th, 1936).

32. Prior to the passage of this section both were included under the heading "Costs of Administration." See 3 GERDEs, op. cit. supra note 14, $\$ \$ 1159-1161$.

33. In re Parker Young Co., C. C. H. Bankr. Serv. \{ 3399 (D. N. H. 1935); 7 ReMrington, Bankruptcy (4th ed. 1934) §3154.968.

34. If the allowances have been paid or ordered paid before the vesting of the jurisdiction of the reorganization court, they must be allowed to stand. In re 7000 South Shore Drive Bldg. Corp., 86 F. (2d) 499 (C. C. A. 7th, 1936); In re Central Shorewood Bldg. Corp., 90 F. (2d) 725 (C. C. A. 7th, 1937); see Shulman v. WilsonSheridan Hotel Co., 301 U. S. 172, 173 (1937). For a discussion of whether an allowance for services rendered and to be rendered is a final order, see (1937) $4 \mathrm{U}$. of CHr. L. Rev. 673; In re Central Shorewood Bldg. Corp., 90 F. (2d) 725 (C.C.A. 7th, 1937).

35. Shulman v. Wilson-Sheridan Hotel Co., 301 U. S. 172 (1937). Allowances were also scaled down in $I n r e$ Allied Owners, Inc., 79 F. (2d) 187 (C. C. A. 2d, 1935) aff'd, sub nomine Callaghan v. R. F. C., 297 U.S. 464 (1936); In re New York Investors, Inc., 79 F. (2d) 182 (C.C.A. 2d, 1935); In re Kelly Springfield Tire Co., 13 F. Supp. 724 (D. MId. 1935), appeal denicd, 82 F. (2d) 1020 (C. C. A. 4th, 1936); In re Davison Chemical Co., 14 F. Supp. 821 (D. Md. 1936). In In re Memphis Strect Ry., 11 F. Supp. 682 (W. D. Tenn., 1935), the fees were allowed as ordered on a per month basis in the prior proceeding without any discussion.

It has been stated that allowances may not be increased. See $I n r c$ New York Investors, Inc., 79 F. (2d) 179, 181 (C. C. A. 2d, 1935), cert. denicd, sub. nom. Endelman v. R. F. C., 296 U. S. 649 (1935). But see In re Central Shorewood Bldg. Corp., 90 F. (2d) 725 (C.C. A. 7 th, 1937). 
tively correct is often followed. ${ }^{36}$ Some courts have also pursued the implication of the statute and have refused to make allowances for services in prior proceedings until the fees had been fixed ly the court appointing the prior trustee or receiver ${ }^{37}$ Additional complications are introduced in cases where reorganization supersedes a prior bankruptey, for it has been held that the discretionary powers conferred on the reorganization judge under Subsection (i) do not affect the operation of Sections $48^{33}$ and $40^{39}$ of the Bankruptcy Act which fix a maximum limit on the fees of trustees, receivers and referees in bankruptcy. ${ }^{\text {th }}$ Since the statute expressly provides for the parment of reasonable adninistrative expenses of prior proceedings, there seems to be no problem as to whether or not allowances for fees should be preferred orer other clains against the estate. Even if the fees are reduced in the reorganization proceeding, the court will probably provide for the immediate payment of the determined amount and will certainly insist that provision for parment he included in the reorganization plan. ${ }^{41}$

While "administrative expenses and allowances" may be scaled down by the $7 \mathrm{H}$ court, bona fide third party obligations of the prior proceeding must probably be paiu in full.2. The statutery mandate that such obligations shall be "protected" has been interpreted to mean that the reorganization court must exercise its independent judgment as to their validity and terms, ${ }^{43}$ and. in some cases. postpone prayment for a limited perionl of time. ${ }^{44}$ The decisions may be rationalized according to the nature of the various claims inrolvel and according to the elfect which immediate payment would have upon the ultimate reorganization. s5 $^{5}$ Thus supply and wage claims, as well as other ruming expenses of the prior procecling, will probably be paid as soon as they fall due, provided that the $77 \mathrm{~B}$ court is satisfied as to their validity: ${ }^{46}$ Current operating charges of this type must be incurred if the

36. See In re Davison Chemical Co.. 14 F. Supp. $\$ 21,840$ (1). Md. 1936) : (jrossman v. Kridel, 90 F. (2d) 624 (C. C. A. 2d. 193\%).

37. In $r e$ 2l1 Eait I lolaware Place IBldg. (“irp. 7 F. Surp. \$92 (E. D. Ill. 1934).

38. 36 Stat. 840 (1910), 11 U. S. C. $\$ 76$ (1934). This sets the compencation of bankruptcy receivers and trustees.

39. 32 Stat. 799 (1903), 11 U. S. C. $\$$ (is(a)(1934). This sectiun sets reicrees' compensation.

40. Callaghan v. R. F. C.. 297 C'. S. 464 (1936).

41. See cases citcd note 35 , supra.

42. See In $r$ Tnited Cigar Stures of Amurica, is F. (2d) 691,693 (C C.A. 2d, 1935).

43. In re Parker-Young Co.. C. C. I1. Ianks. Surv. (.33) (D) X. II 1935),

44. In re Unitcd Cigar Stures of Amuriea. is F. (3.1) 191 (t:. C..A. 2d. 1935). Tlie w rd "protect" is a convenientl: sagu 4 rm which d w wht crprcsily den! rear-

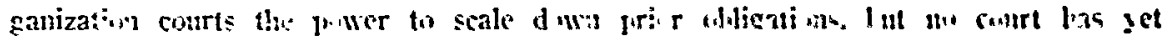
sugresent this prosilibil!.

45. Ji.. at 1,93.

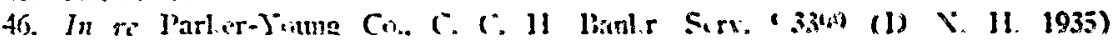

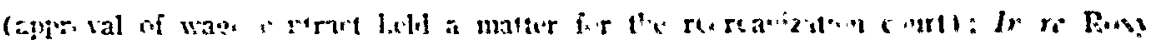


debtor is to continue as a going concern. Since they can usually be paid out of current earnings, the immediate discharge of these obligations will not materially affect the consummation of a reorganization plan. Indeed, failure to satisfy these charges might easily have the effect of impairing the entire reorganization process, by making it increasingly difficult for receivers and trustees to secure the new money and materials essential to the continued operation of the debtor corporation. Although the priority section of the Bankruptcy Act does not apply to Section 77B,77 taxes, ${ }^{48}$ likewise, will ordinarily-be paid as soon as they are adjudicated valid charges against the estate. ${ }^{49}$ Practical considerations usually warrant their immediate payment, especially when delay might entail penalty assessments ${ }^{50}$ or forfeiture of the corporate franchise. ${ }^{51}$

Sometimes, however, obligations will be incurred in prior proceedings which in no way contribute to the final rehabilitation of a debtor corporation. Liquidation dividends declared in prior bankruptcies are illustrative of this class. If these dividends are large and are considered as obligations binding upon the 77B court, immediate payment might jeopardize the entire reorganization. Even if the dividends declared to creditors are small, or have been largely paid off, so that they constitute only a minor share of the total liabilities of the estate, there is little reason for discharging them immediately in the reorganization proceeding. The better practice, and the one actually adopted by the courts, ${ }^{52}$ is to delay any distribution until the final consummation of a plan. They must then probably be paid in full if they were validly declared in the prior proceeding. ${ }^{.3}$

Theatres Corp., C. C. H. Bankr. Serv. $\llbracket 4679$ (S. D. N. Y. 1937) (supply debts incurred in good faith to be paid in full).

47. $\$ 77 \mathrm{~B}(\mathrm{k})$. The priority section does, however, apply when the estate is to be liquidated. See page 270 , infra.

48. Taxes have been held not entitled to priority. In re Central Public Service Corp., C. C. H. Bankr. Serv. $\llbracket 3723$ (D. Md. 1935); cf. In re Pressed Steel Car Co. of N. J., C. C. H. Bankr. Serv. \4745 (W. D. Pa. 1937).

49. In rc Central Public Service Corp., C. C. H. Bankr. Serv. \3723 (D. MI. 1935); Hennepin County, Minn. v. M. W. Savage Factories, Inc., 83 F. (2d) 453 (C. C. A. 8th, 1936), cert. denicd, 299 U. S. 555 (1936); Parsons v. Detroit and Canadian Tunnel Co., 15 F. Supp. 986 (E. D. Mich. 1936). Most taxes falling due during an insolvency proceeding are considered as administrative expenses. Hrar, Recervers (4th ed. 1905) §881a. However, franchise taxes often are held not to be such expenses. In re Pressed Steel Car Co. of New Jersey, C. C. H. Bankr. Serv. $\llbracket 4745$ (W. D. Pa. 1937).

50. County of Spokane v. United States, 279 U. S. 80 (1929); see Rogge, The Difference in the Priority of the United States in Bankruptcy and in Equity Receiverships (1929) 43 HARv. L. Rev. 251, at 260. Interest must also be paid. Board of Commissioners of Sweetwater County, Wyo. v. Bernardin, 74 F. (2d) 809 (C. C. A. 10th, 1934), cert. denied, 295 U. S. 731 (1935).

51. Michigan v. Michigan Trust Co., 286 U. S. 334 (1932).

52. In re United Cigar Stores Co. of America, 78 F. (2d) 691 (C. C. A. 2d, 1935).

53. Ibid. 
In determining whether specific obligations should be paid immediately or postponed, reorganization courts must be governed largely by the expediencies of the particular case involved, for there is little authority upon which they can base their decision. The protection of obligations under Sulsection (i) clearly has no relation to the determination of relative priorities in bankruptcy. The objectives of bankruptcy proceedings are liquidation of the debtor's estate and distribution of assets among the various classes of creditors according to their status under Section 64, the priority section of the act. Since the total assets of the bankrupt are rarely sufficient to satisly all claims against the estate, this section determines what creditors must be paid first. But so far as appears in the cases decided to date, all obligations within the meaning of Subsection (i) must eventually be paid in full, and whether the payment shall be immediate is within the discretion of the court. It is likely that his discretion will be exercised in the light of the priority schedules commonly employed in federal equity receiverships, since the purpose of these proceedings - reluabilitation of the debtor corporation - is identical with that of $77 \mathrm{~B}$ reorganizations, and similar problems are therefore often encountered in determining the order in which various claims inust be paid. In general the order of payment in equity proceedings is: (1) the expenses of the receivership including court costs, fees, costs of preserving the estate, and costs of running the business, payable in the order given $;^{-34}$ (2) six montls claims $;^{55}$ (3) liens given priority by statute $; 6$ (4) secured claims $; 5$ (5) debts due the United States, a statutory

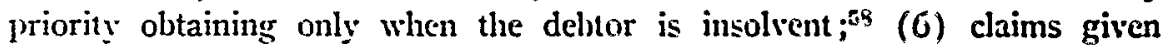
1 priority under local law ; ${ }^{59}(7)$ other debts owed by the corporation. To the extent that the "olligations" of prior proceedings resemble the various components of this list, reorganization courts may find equity precedents helpful in fixing an order of temporal priority under sulsection (i). This schedule, howerer, should not be regarded as determinative by $77 \mathrm{~B}$ courts, for the very fact that no order of priority is siven in the statute indicates an intent

54. Piedmont v. Gainesville and X. IV. R. IR. 30 F. (2d) 525 (X. L. G3. 1929). For a detailed discussion of the priority order in eyuity, ste 2 Gennes, Conronate ReosGANizations (1936) $\$ \$ 639-680$. For a discussion of the priwrities given claims in reorganization proceedings, see Cumment (1937) 85 L". or I'A. I. IRE. 813.

55. See note 19, supra.

56. E.g., for taxes, Rev. Stat. $\$ 3186$ (1875). 26 U. S. C. \$1504 (1434) ; fur rent, Cir: Cone La. (Dart. 1932) Art. 2705: for labur. Ouro Grs. Conk (l'age, 1926) $\$ 8309$ it seq.

57. Sce 2 Gerdes, op. cit. supro nutc 14, \$\$ 115 , 140.

58. Rev. Stat. $\$ 3466$ (1875), 31 U. S. C. $\$ 191$ (1934). This statute dues not give the United States a lien. Nor does it displace liens. Savings and Loun Snciety v. Multnomah County. 169 U. S. 421 (1S98). For a general discussinn of this priority, see Blair, The Priority of the Uniled Slates in liquily Iticciacrshits (1925) 39 IIAnt. L. REr. 1.

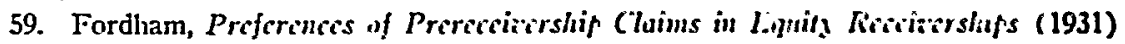
15 MIN. L. REv. 261, 288-290. 
that reorganization courts should have broad discretionary powers over the protection of obligations under Subsection (i).

When a reorganization proceeding commenced under 77B proves unsuccessful, the treatment of costs incurred therein depends upon the subsequent disposition of the estate. If the property is returned to the debtor, the costs of administration may be said to constitute a charge upon the res, and must usually be borne by the debtor itself. ${ }^{60}$ When the property is returned to a trustee or receiver in a prior proceeding, the 77B court must hand it over "upon such terms as the judge may deem equitable for the protection of obligations incurred by any trustee or trustees under this section, and for the payment of administrative expenses and allowances in the proceeding hereunder." 61 Without any mention of this clause, several reorganization courts have deducted the costs of administering the $77 \mathrm{~B}$ proceeding from the total assets of the estate before handing the property over to a prior trustee. ${ }^{62}$ Even where the allowances fixed by the 77B court are not made payable immediately, however, the statute would seem to require that the administrative expenses and obligations of the reorganization must eventually be paid in full by the superseding court.

More complicated problems are presented where the debtor's estate is liquidated under Section $77 \mathrm{~B}(\mathrm{k}){ }^{63}$ This Section provides that, as soon as the order for liquidation is made, the priority sections of the Bankruptcy Act, from which reorganization proceedings are exempt, come into operation, and the usual bankruptcy procedure must be followed. Although it is well settled that the costs of administration in bankruptcy are entitled to priority over unsecured clains ${ }^{64}$ the term, costs of administration, is given a much

60. In re Nine North Church Street, Inc., C. C. H. Bankr. Serv. $\| 4050$ (N. D. N. Y. 1936), aff'd, 89 F. (2d) 13 (C. C. A. 2d, 1937); cf. In re IV. N. Britton Realty Co., C. C. H. Bankr. Serv. $\llbracket 4357$ (W. D. N. Y. 1936). This policy is considered proper in 3 GeRdes, op. cit. supra note $14, \$ 1163$. On the dismissal of an equity receivership either the debtor [Speakman v. Bryan, 61 F. (2d) 430 (C. C. A. 5th, 1932) ; sec Burnrite Coal Briquette Co. v. Riggs, 274 U.S. 208, 214 (1927)], or the person filing the receivership petition [Chicago Title and Trust Co. v. Newman, 187 Fed. 573 (C. C. A. 7th, 1911)], is charged with the expenses of the receivership. It may, therefore, be within the power of the reorganization court to charge a creditor who files the pctition with the reorganization expenses.

61. $\$ 77 B(i)$.

62. Oakland Hotel Co. v. Crocker First Nat. Bank, 85 F. (2d) 959 (C. C. A. 9th, 1936); In re W. N. Britton Realty Co., C. C. H. Bankr. Serv. \4357 (W. D. N. Y. 1936) (properties formerly in foreclosure proceedings turned back to receivers burdened with the reorganization charges allocable to the properties).

63. In liquidation proceedings administrative expenses have sometimes been ordercd paid first, although there has been no discussion of the propriety of this treatment. In $r \mathrm{c}$ Manhattan Music Hall, Inc., 14 F. Supp. 48 (S. D. N. Y. 1936); In rc Green Mountain Syrup Corp., C. C. H. Bankr. Serv. \4238 (S. D. N. Y. 1936).

67. Section 64 (b) (3) gives the costs of administration in a bankruptcy procecding a specific priority over unsecured claims; secured claims, however, are usually protected 
narrower significance in bankruptcy than in reorganization. Disputes have, therefore, arisen as to whether various costs recognizable under 77B are entitled to priority in a subsequent liquidation. Typical of these disputes is the problem centering around the compensation of creditors' attorneys. It lias been held that Section $77 B(c)(9)$, which provides for the payment of such compensation in $77 \mathrm{~B}$ proceedings, applies to liquidation as well, and hence takes precedence over $64(\mathrm{~b}),{ }^{65}$ the priority section of the act. But another court has held that it only applies to suceessful reorganizations. ${ }^{\text {CE }}$ Equally confusing is the treatment of obligations incurred in the $77 \mathrm{~B}$ proceeding. These obligations may include any of the numerous costs incurred by the trustee in operating the business of the debtor while in reorganization, but, since Section 64 is strictly construed, the only claims which will be entitled to priority under this section in a subsequent liquidation are those related to the preservation of the debtor's estate. ${ }^{.7}$ In certain cases, however, priority might be granted under a different rationale. Section $77 B$ (c) (3) empowers reorganization courts to authorize the issuance of certificates for cash or other considerations and to grant them stch priority over steured and unsecured clains as shall be lawful in the particular case. ${ }^{69}$ When prior obligations are represented by these certificates, they may be given the stated priority under Section $(5)$ (d) which provides for the protection of liens validly incurred prior to the commencement of the liquidation proceeding.

by Section 67 (d) which take precedence nisc Scction 64. In re llwwell and hing Co., Inc, 16 F. Supp. 984 (M. D. Pa. 193\%). Dut thrse expenses which represent the costs of preserving the property in which grior lisus attach. wr the ensts wit saie of the property and of bringing it into court. talic priority ower licnlulders. In re Irel I lisplays,

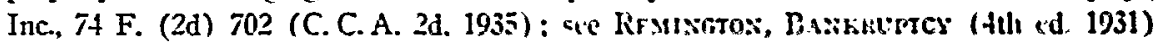
$\$ \S 446.2613,2631,2662$.

65. Oakland Hotel Co. v. Crocker First Nat. Rank. 85 I. (2d) 959 (C. C. A. 9 th. 1936) ; In rc Green MYountain Syrup Corp. C. C. If. Bankr. Serv. [ 4233 (S. D. X. Y. 1936).

66. In re Mfanhattan Music Hall, Ine., 14 F. Suln. 48 (S. D. ‥ L. 1936 ).

67. See note 64, sipra.

68. The "where lawful" phrase may mean that, as in recucerships, etspnses ni ruming the business can be given priority over secured claims only when the lienholders have so authorized. See notes 18. 22, sufra. Fur a decision which apparently decides against this possibility, see In $r$ Prima C0. \&S F. (2d) 785 (C. C. A. 7th, 1937), (1937) 85 U. of P.1. L. Rer. 736. 